УДК 347.45/47

DOI 10.37749/2308-9636-2019-12(204)-1

\title{
В. В. Спасибо,
}

\section{ҐЕНЕЗА НОРМАТИВНО-ПРАВОВОГО РЕГУЛЮВАННЯ АЕРОПОРТОВОГО ОБСЛУГОВУВАННЯ В УКРАЇНІ}

У статті досліджено генезу норлативно-правового регулювання иивільних правовідносин з аеропортового обслуговування в Україні. Зроблено висновок, шо діяльність з аеропортового обслуговування регулюється не лише норлали Цивільного й Повітряного кодексів та Авіаційних правил України, але й норлали адліністративного, господарського, податкового, трудового, екологічного, зелельного вітчизняного законодавства та іншими його галузяли.

Ключові слова: норлативно-правове регулювання, иивільно-правові відносини, иивільне законодавство, аеропортове обслуговування, Повітряний кодекс України, Авіаційні правила Украӥни.

Становлення й розвиток нормативноправового регулювання цивільних правовідносин з аеропортового обслуговування на теренах колишнього СРСР, насамперед в Україні, відбувалось одночасно з розвитком повітроплавання та цивільних повітряних перевезень. Законодавче регулювання в цих сферах формувалося як сукупність норм, що регулюють перевезення, а згодом до нього приєдналось і законодавство з надання послуг.

Питання нормативно-правового регулювання аеропортового обслуговування певною мірою знайшли відображення у працях таких представників науки цивільного права як Т. В. Боднар, В. І. Борисова, М. І. Брагінський, О. Воловик, А. Б. Гриняк, О. В. Дзера, В. І. Дрішлюк, О. С. Іоффе, О. О. Красавчіков, О. Д. Крупчан, Н. С. Кузнецова, В. В. Луць, Р. А. Майданик, О. В. Мороз, М. Д. Пленюк, О. О. Первомайський, С. О. Погрібний, Н. А. Саніахметов, I. А. Селіванова, В. I. Синайський, M. М. Сібільов, О. М. Соловйов, I. В. Спасибо-Фатєєва, О. А. Сурженко, Ю. К. Толстой, Є. О. Харитонов, Г. Ф. Шершеневич, С. I. Шимон, В. Л. Яроцький та інших.

Метою статті є визначення генез нормативно-правового регулювання аеропортового обслуговування в Україні.
Одним із об'єктів, де починається і саме перевезення як послуга, й ті додаткові послуги, без яких неможливе перевезення повітряним транспортом, є аеродром.

У 1912 р. відомий російський авіаційний інженер, історик i популяризатор авіації К. Е. Вейгелін писав, що для належного розвитку авіації необхідно відповідними узаконеннями врегулювати, точніше, створити Кодекс повітряного права, яким би мали вирішуватися всі питання, пов'язані з польотами [1, с. 125]. Однак у часи Російської імперії такий кодекс та інші нормативно-правові акти, які б системно врегульовували питання повітряних польотів, повітряних перевезень та пов'язаного з цим аеропортового обслуговування, так і не були прийняті. Між тим існували окремі розпорядження, накази й навіть міжнародні угоди, наприклад, про порядок польотів повітряних куль, укладені між Росією та Німеччиною y $1896-1897$ pp. [2, c. $184-185$ ].

1917-1932 роки можна охарактеризувати як період первинного формування нормативно-правової бази РСФСР і СРСР з регулювання майнових відносин у сфеpi наземного забезпечення авіаційних перевезень. Це було обумовлено стрімким розвитком літакобудування, розбудовою аеродромів, перших аеропортів, започаткуванням внутрішніх регулярних повіт- 
ряних перевезень, а також відкриттям міжнародних рейсів. У результаті з'явилася велика кількість декретів, указів, розпоряджень, інших актів, серед яких можна виділити Декрет Ради Народних Комісарів РРФСР «Про повітряні пересування» від 17.01.1921 p. [3], Постанову Ради праці та оборони СРСР «Про порядок відведення військовому відомству земельних ділянок для облаштування аеродромів та посадкових майданчиків» від 28.09.1923 р. [4], «Положення про Головне Управління Робітничо-Селянського Червоного Повітряного Флоту» від 13.09.1921 p. [5], «Положення про Дивізіон спеціалістів Червоного Повітряного Флоту» від 03.11.1921 р. [6], Постанову Ради праці та оборони СРСР «Про покладання технічного нагляду за повітряними лініями на Головне управління повітряного флоту і про організацію Ради з цивільної авіації» від 09.02.1923 р. [7].

Перший аеропорт в Україні було засновано 1923 р. у Харкові, в Сокольниках. 3 25.05.1924 р. почали виконуватися регулярні рейси за маршрутами Харків - Київ і Харків - Одеса, а вже в 1931 р. були відкриті рейси Харків Ростов - Мінеральні води - Орджонікідзе - Баку і Харків - Дніпропетровськ - Кривий Ріг - Миколаїв Одеса [8, с. 153].

Регулювання відносин у сфері надання послуг аеропортами здійснювалося нормами Цивільного кодексу УРСР 1922 р. [9], відповідно до статей 21 і 22 якого земля, націоналізовані підприємства, їх обладнання, націоналізовані споруди визнавались власністю держави i не могли бути предметом приватного обороту. Вони могли здаватися в оренду в установленому законом порядку. До таких об'єктів відносились і літальні апарати, які визначалися виключно об'єктами права власності держави.

Станом на 1932 р. була накопичена достатня кількість норм, що регулюють діяльність із наземного обслуговування в аеропортах. Об'єктивно були створені умови для систематизації й упорядкування всього масиву таких норм. Це було вирішено в першому Повітряному ко- дексі СРСР 1932 р. [10] (далі - Кодекс), а в подальшому - в інших повітряних кодексах, яких чимало приймалося в радянські часи, що само по собі свідчить про значення, яке надавалося законодавчому регулюванню саме цієї сфери суспільних відносин - послуг із повітряних перевезень та наземного обслуговування. Крім того, простежується тенденція, що такі відносини регулюються комплексно як пов'язані безпосередньо з державним управлінням у цій галузі.

У гл. IV Кодексу аеропорт розглядався не як суб'єкт, а як об'єкт права, про що свідчить обов'язок здійснення реєстрації аеропортів, аеродромів, постійних посадочних майданчиків у Головному управлінні цивільного повітряного флоту. Крім того, було передбачено право передати цивільний аеропорт, аеродром, постійний посадочний майданчик і причальну точку в експлуатацію іншій установі, підприємству, організації або особі, а також знести або надати інше призначення земному обладнанню для польотів. Проте Кодекс не містив будь-яких обмежень щодо форми власності на такі об'єкти.

У ч. 1 ст. 29 Кодексу зазначено, що цивільні аеропорти, аеродроми, посадочні майданчики та причальні точки могли входити до складу так званих «повітряних ліній», під якими розумілись усі організації повітряного сполучення між певними пунктами однією або кількома трасами, тобто земною чи водною поверхнею, обладнаною для обслуговування повітряних ліній. Із цієї норми випливає, що аеропорт як об'єкт права, будучи єдиним майновим комплексом, є частиною ще одного складного об'єкта, а точніше єдиного майнового комплексу - повітряної лінії. Більш детального опису цього «супероб'єкта» права Повітряний кодекс, на жаль, не містив. Окрім того, у ч. 1 ст. 29 Кодексу було закріплено державне регулювання тарифів «за користування» аеропортом, аеродромом, причальною точкою, посадочним майданчиком. Перелік послуг, які підлягали тарифікації, на рівні Кодексу не було врегульовано, а отже, цими повноваження- 
ми були наділені відповідні органи виконавчої влади.

Після ухвалення першого Повітряного кодексу СРСР до Цивільного кодексу УРСР були внесені зміни. Зокрема, його ст. 22 було доповнено приміткою про те, що купувати цивільні повітряні судна, мотори до них та інше авіаційне й повітроплавне майно, що до них відноситься, можуть тільки установи, підприємства, громадські організації та особи, які можуть володіти цивільними повітряними суднами та експлуатувати їх на підставі ст. 7 Кодексу. Цим було започатковано практику регулювання цивільних правовідносин у сфері, що розглядається, нормами не Цивільного, а Повітряного кодексу. Тому аналіз подальшого розвитку законодавства, що регулює такі правовідносини, доцільно провадити з урахуванням норм як Цивільних кодексів УРСР та СРСР, так і Повітряних кодексів.

Нова редакція Повітряного кодексу СРСР була прийнята в 1935 р. [11]. До його ст. 32 було вперше введено норму про обов'язковість відповідності наземного обладнання для польотів вимогам, що встановлювалися Головним управлінням цивільного повітряного флоту. При цьому Головне управління, окрім проведення реєстрації наземного обладнання, стало видавати посвідчення про їх придатність до експлуатації. Таким чином, у 1935 р. було розпочато роботу над державною стандартизацією наземного обладнання та введено обов'язковість його попередньої оцінки на відповідність.

Нові редакції Повітряного кодексу CPCP, видані в 1938 та 1946 рр. [12; 13], не містили в собі суттєвих змін з питань, що $€$ предметом даного дослідження. Навпаки, наступна редакція Повітряного кодексу СРСР, затверджена Указом Президії Верховної Ради СРСР від 26.12.1961 р. [14], включала цілу низку принципово нових норм. Ним було чітко окреслено основну мету аеродромів та аеропортів, а саме: обслуговування повітряних суден, що здійснюють польоти з метою перевезення пасажирів, багажу, вантажів і пошти; виконання спеціальних робіт в окремих галузях народного господарства (застосування авіації в сільському господарстві, для охорони лісів, аерофотозйомки і т. ін.); надання медичної та іншої допомоги населенню й проведення санітарних заходів; проведення дослідницьких, експериментальних i науково-дослідних робіт; для навчальних, культурно-освітніх і спортивних цілей. Аеродром визначався як земельна або водна ділянка, спеціально обладнана для зльоту, посадки, стоянки та обслуговування повітряних суден. Було перелічено обов'язки осіб, які здійснюють експлуатацію аеродромів: постійне підтримання аеродромних споруд у стані, придатному для їх експлуатації; своєчасний прийом і випуск у політ повітряних суден; технічне обслуговування повітряних суден; керівництво рухом повітряних суден в аеродромній зоні та на повітряних трасах. Були уточнені та розширені вимоги стосовно безпеки будівництва в районах аеропортів та аеродромів. Аеропорти стали розглядатися не як об’єкти, а як суб'єкти права, підприємства, що здійснюють регулярні прийом i відправку пасажирів, багажу, вантажів і пошти, організацію та обслуговування польотів повітряних суден і мають для цих цілей аеродром, вокзал, інші наземні споруди, а також необхідне обладнання. Одночасно вперше було введено норму про поділ аеропортів на класи та обов'язок забезпечити облаштування аеропортів відповідно до їх класу. На місцеві органи влади було покладено обов'язок здійснювати будівництво, реконструкцію, благоустрій та експлуатацію під’їзних доріг до аеропортів, регулярний рух пасажирського транспорту на цих дорогах, а також телефонний зв'язок міст з аеропортами.

Редакція Повітряного кодексу СРСР, затверджена Указом Президії Верховної Ради СРСР від 11.05.1983 р. № 9275-Х [15], в основному відтворювала положення попередньої редакції цього документа. Серед нових норм можна відзначити насамперед введення норми, спрямованої на уніфікацію внутрішнього законо- 
давства СРCP з питань аеропортової діяльності з документами Міжнародної організації цивільної авіації (ІКАО), зокрема необхідність отримання сертифіката придатності аеродрому до експлуатації при відповідному метеорологічному мінімумі категорії IКАО.

Перший Повітряний кодекс України (далі - ПК України), прийнятий у 1993 р. [16], майже не приділяв уваги питанням нормативно-правового регулювання аеропортового обслуговування. Поза увагою залишилися питання права власності на аеродроми та аеропорти, в тому числі можливості їх продажу або іншої форми відчуження. При цьому показово, що Закон УРСР «Про власність» [17] прямо не визначав аеропорти та аеродроми як майно, що може знаходитися виключно в державній власності. Водночас Закон УРСР «Про підприємництво» [18] не відносив діяльність щодо надання послуг з аеропортового обслуговування до видів діяльності, які могли здійснюватися виключно державними підриємствами.

Новий Цивільний кодекс України [19] (далі - ЦК України) також не привніс нових системних рішень у ці питання. Певною мірою законодавче регулювання, надане цим кодексом, позитивно відбилося на відносинах у сфері надання аеропортових послуг (ст. 6), зокрема щодо укладення різних договорів i формування їх моделей, спираючись на принцип свободи договору. Окремі його норми стосуються послуг у сфері перевезень, які відсилають до спеціального законодавства або до договору (ст. 908). Зокрема, перевезення вантажу, пасажирів, багажу, пошти здійснюється за договором перевезення.

Слід зазначити, що зміни до першого Повітряного кодексу України, які були внесені в 1997-2011 рр., не стосувалися питань організації діяльності аеропортів та аеродромів і порядку укладення договорів на аеропортове обслуговування. У 2011 р. було прийнято нову редакцію ПК України [20], який принципово відрізнявся від своїх попередників і за структурою, і за змістом. Зокрема, вперше у ст. 1 ПК України було систематизовано термінологію, в алфавітному порядку викладено норми-дефініції. При цьому при тлумаченні термінів «аеродром» i «аеропорт» законодавець повернувся до їх розуміння як об'єктів права, складних об'єктів. Уперше був наданий перелік об'єктів, які мали входити до складу аеродрому (аеродромні об'єкти): поверхні (штучні, грунтові або водні), призначені для посадки, зльоту, руху, стоянки повітряних суден, руху наземного транспорту на території аеродрому; грунтові елементи аеродрому; об'єкти обслуговування повітряного руху; засоби зв'язку, навігації та спостереження; візуальні засоби забезпечення польотів; електрозабезпечення аеродрому; об’єкти та засоби аварійно-рятувального, протипожежного забезпечення, забезпечення авіаційної безпеки, метеорологічного обслуговування, споруди та мережі інженерних комунікацій, що забезпечують роботу аеродромних об'єктів.

Уперше на рівні кодексу вводилося поняття «експлуатант аеродрому» $\mathrm{i}$ визначалися його обов'язки. При цьому окремо були наведені обов'язки конкретно керівника експлуатанта як фізичної, посадової особи. ПК України прямо визначав ступінь цивільної оборотоздатності аеродромів. Було зазначено, що аеродроми та аеродромні об'єкти (злітнопосадкові смуги, руліжні доріжки, перони, інші елементи аеродромів), що забезпечують безпеку польотів та перебувають у державній чи комунальній власності, не підлягають відчуженню, продажу, приватизації, обміну, передачі в заставу. Разом із тим надано право стосовно єдиних майнових комплексів, а також окремих об'єктів інфраструктури, призначених для наземного обслуговування повітряних суден, пасажирів, екіпажів, обробки багажу, пошти, вантажу, об’єктів неавіаційних видів діяльності, укладати договори про їх передачу в концесію, оренду в установленому законодавством порядку, за умови, що не змінюється цільове призначення таких об'єктів. Також було надано право укладати стосовно державних та/або кому- 
нальних аеродромів договори про передачу їх приватному інвестору в оренду, концесію, управління, а також бути предметом інших договорів, що укладаються за правилами, визначеними законодавством України, за умови заборони зміни цільового призначення об'єктів аеродрому, що забезпечують його основну виробничу діяльність [20].

ПК України передбачалося, що експлуатант аеропорту може бути одночасно й експлуатантом аеродрому, або ці особи можуть не збігатися. Тобто законодавець використовує доволі специфічний термін задля визначення суб'єкта прав на майно, яким є аеропорт. Цей термін є доволі містким й увібрав у себе як можливість користування аеропортом, так і управління ним, зробивши акцент на зацікавленості цього суб'єкта здійснювати дії задля покращення майнового стану цього об’єкта.

Також ПК України вперше прямо передбачив норму, згідно з якою експлуатанту аеропорту надавалося право за своїм рішенням або самостійно надавати послуги в аеропорту, або на договірних умовах передавати право на наземне обслуговування в аеропорту юридичним чи фізичним особам, що відповідають вимогам Авіаційних правил України [21]. Цим було закладено засади для розвитку мережі договорів між експлуатантом аеропорту та іншими особами, які виконують ті чи інші дії з надання різноманітних послуг. При цьому надання таких послуг може бути як автономним від інших надавачів послуг, так і взаємоузгодженим майже до правової конструкції субдоговору.

ПК України містив також низку норм, спрямованих на запобігання недобросовісній конкуренції у сфері діяльності аеропортів за двома окремими напрямами: а) неконкурентні дії експлуатанта аеропорту відносно авіаперевізників; i б) неконкурентні дії експлуатанта аеропорту відносно інших осіб, які провадять діяльність на території аеропорту. Це відповідає ч. 5 ст. 13 ЦК України і застосовується задля додержання прав уповноваженої особи [19].
Таким чином, 3 прийняттям нового Повітряного кодексу України 2011 р., який містив цивільно-правові норми [20], зроблено значний крок на шляху нормативно-правового регулювання аеропортового обслуговування. I хоча такі норми здебільшого були новими для вітчизняного правового простору, аналогічні норми вже багато років діяли в законодавстві інших країн і навіть у міжнародному праві. Уже на час прийняття в Україні Повітряного кодексу вони застосовувалися в європейських країнах, оскільки містилися в договорах і деяких інших актах Міжнародного приватного повітряного права (МПрПП).

Взагалі регулюванню повітряних перевезень присвячено чимало правових міжнародних актів, що застосовуються для регулювання відповідних цивільних відносин, як про це зазначається у ст. 10 ЦК України та законах «Про міжнародні договори України» [22] і «Про міжнародне приватне право» [23]. Так, першим міжнародним документом 3 повітряного права стала Конвенція про регулювання повітряної навігації (Паризька конвенція), підписана 13.10.1919 р. урядами США, Бельгії, Болівії, Бразилії, Британської імперії, Китаю, Куби, Еквадору, Франції, Греції, Гватемали, Гаїті, Хіджазу, Гондурасу, Італії, Японії, Лібеpiï, Нікарагуа, Панами, Перу, Польщі, Португалії, Румунії, Держави Сербії, Хорватії, Словенії, Сіаму, Чехословаччини і Уругваю [24]. Зокрема, Конвенцією закріплено основоположний принцип рівності прав користування аеродромами для повітряних суден незалежно від їх державної належності.

Повністю ідентичні норми були згодом відтворені в Іберо-американській (Мадридській) конвенції щодо аеронавігації [25], підписаній у жовтні 1926 р. Окрім країн-підписантів Паризької конвенції, їі норми зобов'язалися виконувати уряди Іспанії, Аргентини, Колумбії, Коста-Рики, Чилі, Домініканської Республіки, Еквадору, Сальвадору, Мексики, Парагваю та Венесуели.

20.02.1928 р. була підписана Панамериканська конвенція з комерційної авіа- 
ції [26]. Серед норм цієї Конвенції слід виділити правило про можливість обмеження каботажу (ст. 22), а саме право кожної договірної держави встановлювати застереження й обмеження на користь своїх власних національних повітряних суден щодо комерційних перевезень пасажирів і товарів між двома або більше точками на їх територію, а також на інші оплачувані авіаційні операції повністю в межах своїх територій. Також нормами ст. 23 Конвенції визнано право кожної держави-підписанта самостійно регулювати внутрішнім законодавством створення та експлуатацію аеродромів.

Варшавська конвенція 1929 р. «Про уніфікацію деяких правил, що стосуються міжнародних повітряних перевезень (Гамбурзькі правила)» [27] вважається одним із основоположних документів у сфері міжнародного повітряного права.

Буенос-Айреська конвенція «Про транзит літаків» 1935 р. [28] містила кілька важливих норм-принципів. Поперше, країни-підписанти зобов'язались утримуватися від введення будь-яких податків або мит за транзитний політ повітряного судна над своєю територією. По-друге, за державами залишалось право самостійно встановлювати ставки винагородити за послуги, що надаються або можуть надаватися в аеропортах.

Бухарестська конвенція 1936 р. і Земанська угода 1937 р. не внесли принципово нових норм у врегулювання питань 3 надання послуг аеропортів і припинили дію разом із Буенос-Айреською конвенцією 1935 р. після прийняття Чиказької конвенції про міжнародну цивільну авіацію [29].

У Чиказькій конвенції були систематизовані й упорядковані практично всі норми попередніх міжнародних конвенцій $з$ питань цивільної авіації, а також запроваджені принципово нові норми. Поряд із цим було уточнено принцип рівності визначення ставок зборів за аеропортове обслуговування і вперше введено правило про заборону фінансової дискримінації окремо для регулярних i для нерегулярних сполучень. Окрім то- го, у Конвенції передбачалася можливість обговорення уведених державою ставок зборів за аеропортове обслуговування Радою новоствореної особи Міжнародною організацією цивільної авіації (IKAO), яка мала право надавати рекомендації для розгляду. Було введено пряму заборону стягнення будь-якої оплати лише за право транзиту через територію певної держави чи вліт/виліт на/з їі території будь-якого повітряного судна договірної держави або присутніх на ньому осіб, або майна. Також Конвенція містила комплекс норм, спрямованих на поступову уніфікацію не лише технічного забезпечення польотів, а i їх нормативного регулювання. Це стосується, зокрема, обов'язку кожної договірної держави приймати i вводити в дію належні стандартні системи експлуатаційної практики та правил, які час від часу можуть рекомендуватися або встановлюватися згідно з цією Конвенцією.

Важливість Чиказької конвенції полягає і в тому, що окрім власне безпосереднього регулювання певних відносин, нею була створена нова постійно діюча організація - IКАО, яка складається з Асамблеї, Ради та інших органів, які можуть бути необхідними. У 1992 р. Україна стала членом IКАО.

IКАО наділена правом приймати і в разі потреби змінювати міжнародні стандарти, рекомендовану практику й процедури, що стосуються характеристик аеропортів і посадкових майданчиків, надавати різноманітні послуги пасажирам, у тому числі щодо проходження митних та імміграційних процедур, а також 3 інших питань у сфері безпеки, регулярності та ефективності аеронавігації, які час від часу можуть виявитися доцільними.

Сьогодні є прийнятими й діють 18 стандартів, які $є$ додатками до Чиказької конвенції, один із яких (додаток № 14 «Аеродроми») присвячений їх проектуванню та експлуатації. Також є прийнятими і діють декілька надзвичайно важливих документів, таких як: «Керівництво з економіки аеропортів», «Політика IКАО по відношенню до аеропор- 
тових зборів та зборів за аеронавігаційне обслуговування», «Комерціалізація та приватизація аеропортів і постачальників послуг з аеронавігації», «Керівництво по аеродромам для повітряних суден короткого зльоту та посадки», «Керівництво 3 проектування аеродромів», «Керівництво 3 проектування аеропортів» та ін.

Слід зазначити, що Україна у сфері міжнародних повітряних перевезень дотримується норм Варшавської конвенції (3 1959 р.), Гаазького протоколу (з 1963 р.) та Гвадалахарської конвенції (з 1984 р.), стороною решти міжнародних договорів Україна не була. Тим не менш, протягом останніх десятиліть провадиться поступова політика з уніфікації внутрішнього законодавства України із стандартами та рекомендованою практикою IKAO.

Нормативно-правове регулювання у сфері цивільної авіації здійснюється шляхом прийняття уповноваженим органом держави Авіаційних правил України, що регулюють діяльність цивільної авіації та використання повітряного простору України. Вони розробляються відповідно до стандартів і рекомендованої практики IКАО, нормативних актів Міжнародної асоціації повітряного транспорту (IАТА), Свропейської організації з безпеки аеронавігації (Свроконтролю), інших міжнародних авіаційних організацій та з урахуванням законодавства Свропейського Союзу в галузі цивільної авіації.

Серед важливих міжнародних документів, що стосуються нормативно-правового регулювання аеропортового обслуговування, слід відзначити й Директиву Ради СС «Щодо доступу до ринку послуг з наземного обслуговування у аеропортах Спільноти» [30], положення якої також послідовно імплементуються в норми внутрішнього законодавства України.

Висновки. Дослідження ґенез нормативно-правового регулювання відносин у сфері надання аеропортових послуг дозволяє дійти таких висновків. Аеропортові послуги та їх законодавче регулю- вання безпосередньо пов’язані з послугами з повітряного перевезення. Із поступовим розширенням сфери цих послуг розвивалося й аеропортове обслуговування. Обидва види послуг почали формуватися на початку XX ст. і стрімко розвивалися зі створенням мережі аеропортів у всьому світі, в тому числі в Україні. При цьому законодавче регулювання формувалося як сукупність норм, що регулюють перевезення, а згодом до нього приєдналося й законодавство з надання послуг.

Встановлено, що цивільне законодавство з аеропортової діяльності історично було додатком до законодавства про авіаперевезення, основною метою якого було дотримання гарантій авіабезпеки. Особливістю цивільного законодавства України, що регулює діяльність з аеропортового обслуговування, є те, що його базисні норми містяться не в Цивільному кодексі України, а в нормах інших законодавчих і підзаконних актів - у Повітряному кодексі та в Авіаційних правилах України.

Наголошено, що послуги з аеропортового обслуговування в силу своєї специфіки піддаються нормативному регулюванню не лише з боку цивільного, але й адміністративного, господарського, податкового, трудового, екологічного, земельного законодавства та інших його галузей. Проте ядро комплексу відповідних норм становлять саме норми цивільного права. Це дозволяє врегульовувати зазначені правовідносини із застосуванням принципів і методів цивільного права й водночас враховувати зв'язки між окремими галузями законодавства як елементи системи.

Зроблено висновок, що законодавство України з надання аеропортових послуг має розвиватися в процесі його уніфікації з директивами ЄС, стандартами та рекомендованою практикою Міжнародної організації цивільної авіації, що зумовлено світовими процесами впливу глобалізації на ці відносини і взятими Україною міжнародними зобов'язаннями. 


\section{Список використаної літе ратури}

1. Вейгелин К. Е. Завоевание воздушного океана. История и современное состояние воздухоплавания. Санкт-Петербург: Книгоиздательство П. П. Сойкина, 1912. 168 с.

2. Плеханов А. А., Плеханов А. М. Отдельный корпус пограничной стражи императорской России (1893-1917): исторический очерк. Москва: Граница, 2003. 287 с.

3. О воздушных передвижениях: Декрет СНК РСФСР от 17.01.1921 г. URL: http://www. consultant.ru/cons/cgi/online.cgi?req=doc\&base=ESU\&n=9422\#05862290638342331.

4. О порядке отвода военному ведомству земельных участков для устройства аэродромов и посадочных площадок: Постановление Совета труда и обороны CCCP от 28.09.1923 г. URL: http://wfi.lomasm.ru/pyсский.постановления_CCCP_1917-1992.

5. Положение о Главном Управлении Рабоче-Крестьянского Красного Воздушного Флота: утверждено приказом Председателя Революционного Военного Совета Республики от 13.09.1921 г. № 2186. URL: http://www.alppp.ru/law/zakonodatelstvo-ob-oborone/51/prikazrevvoensoveta-rsfsr-ot-03-10-1921-2186.html.

6. Положение о Дивизионе специалистов Красного Воздушного Флота: утверждено приказом Председателя Революционного Военного Совета Республики от 03.11.1921 г. № 2476. URL: http://www.alppp.ru/law/zakonodatelstvo-ob-oborone/51/prikaz-revvoensoveta-rsfsr-ot03-11-1921-2476.html.

7. О возложении технического надзора за воздушными линиями на Главное управление воздушного флота и об организации Совета по гражданской авиации: Постановление Совета труда и обороны от 09.02.1923 p. URL: https://ru.wikipedia.org/wiki/\% D0\% 92\% D0\% BE\% D0 \% B7\% D0 \% B4\% D1 \% 83\% D1\% 88\% D0 \% BD \% D1\% 8B \% D0\% B9_\% D1 \% 82\% \% 81\% .

8. История отечественной гражданской авиации / под ред. И. А. Филатова. Москва: Воздушный транспорт, 1996. 584 с.

9. Цивільний кодекс Української PCP 1922 p. URL: https://yurist-online.org/laws/codes/ ex/civilnyi_kodeks_usrr_1922.pdf.

10. Воздушный кодекс СССР 1932 г. Москва: РИО Аэрофлота, 1932.

11. Воздушный кодекс СССР 1935 г. Москва: РИО Аэрофлота, 1935.

12. Воздушный кодекс СССР с исправлениями и дополнениями по состоянию на 1 января 1938 г. Москва: РИО Аэрофлота, 1938.

13. Воздушный кодекс СССР с исправлениями и дополнениями по состоянию на 1 января 1946 г. Москва: РИО Аэрофлота, 1946.

14. Воздушный кодекс СССР: утвержден Указом Президиума Верховного Совета СССР 26.12.1961 г. Ведомости Верховного Совета СССР. 1961. № 52. Ст. 538.

15. Воздушный кодекс CССР: утвержден Указом Президиума Верховного Совета СССР от 11.05.1983 г. № 9275-х. Ведомости Верховного Совета СССР. 1983. № 20. Ст. 303.

16. Повітряний кодекс України від 04.05.1993 р. № 3167-XII. Відомості Верховної Ради України. 1993. № 25. Ст. 274.

17. Про власність: Закон УРСР від 07.02.1991 р. № 697-ХII. Відомості Верховної Ради УРСР. 1991. № 20. Ст. 249.

18. Про підприємництво: Закон УРСР від 07.021991 р. № 698-XII. Відомості Верховної Ради УРСР. 1991. № 14. Ст. 168.

19. Цивільний кодекс України від 16.01.2003 p. № 435-IV. Офіційний вісник України. 2003. № 11. Ст. 461.

20. Повітряний кодекс України від 19.05.2011 р. № 3393-VI. Відомості Верховної Ради України. 2011. № 48-49. Ст. 536.

21. Про затвердження Авіаційних правил України «Порядок надання і анулювання прав на експлуатацію повітряних ліній»: наказ Державної авіаційної служби України від 24.10.2014 р. № 686. Офіційний вісник України. 2015. № 42. Ст. 1345.

22. Про міжнародні договори України: Закон України від 29.06.2004 р. № 1906-IV. Відомості Верховної Ради України. 2004. № 50. Ст. 540.

23. Про міжнародне приватне право: Закон України від 23.06.2005 р. № 2709-IV. Відомості Верховної Ради України. 2005. № 32. Ст. 422.

24. Конвенція про регулювання повітряної навігації (Паризька конвенція) від 13.10.1919 p. URL: http://www.spacelaw.olemiss.edu/library/ aviation/IntAgr/multilateral/1919_Paris_conevention.pdf. 
25. Іберо-американська (Мадридська) конвенція щодо аеронавігації. URL: http:// www.sct. gob.mx/fileadmin/_migrated/content_uploads/3_Decreto_por_el_cual_se_promulga_el_Convenio_ Iberoamericano.pdf.

26. Панамериканська (Гаванська) конвенція про цивільну авіацію від 20.02.1928 р. URL: https://www.loc.gov/law/help/us-treaties/bevans/m-ust000002-0698.pdf.

27. Варшавская конвенция 1929 г. об унификации некоторых правил, касающихся международных воздушных перевозок (Гамбургские правила), г. Варшава, 12.10.1929 г. URL: http://www.afr.kz/index_f/warsaw-convention_protocol.pdf.

28. Конвенція про транзит літаків (Буенос-Айреська конвенція) від 19.06.1935 p. URL: http://www.sct.gob.mx/JURE/doc/160-transito-aviones-1935.pdf.

29. Чиказька конвенція про міжнародну цивільну авіацію від 07.12.1944 p. URL: http:// zakon2.rada.gov.ua/laws/show/995_038.

30. Щодо доступу до ринку послуг з наземного обслуговування у аеропортах Спільноти: Директива Ради Європейської спільноти № 96/67/ЄC від 15.10.1996 p. URL: http://www.amc. gov.ua/amku/doccatalog/ document?id=132043\&schema=main.

\section{References}

1. Weigelin K. E. Conquest of the air ocean. History and current state of aviation. St. Petersburg: P. Soikin's Book Publishing House, 1912. 168 p.

2. A. A. Plekhanov, A. M. Plekhanov Separate Border Guard Corps Imperial Russia (1893-1917): a historical sketch. Moscow: Border. 2003. 287 p.

3. On air traffic: Decree of the SNK of the RSFSR from January 17, 1921. URL: http:// www.consultant.ru/cons/cgi/online.cgi?req=doc\&base=ESU\&n=9422 \# 05862290638342331.

4. About the order of allotment to the military department of land plots for the arrangement of airfields and landing sites: Resolution of the Labor and Defense Council of the USSR from September 28, 1923.

5. Regulation on the Main Directorate of the Peasant Red Air Fleet: approved by order of the Chairman of the Revolutionary Military Council of the Republic of 21.09.1921 No. 2186. URL: http://www.alppp.ru/law/zakonodatelstvo-ob-oborone/51/view-revvoensoveta-rsfsr-ot-03-10-1921— 2186. html.

6. Regulations on the Division of Specialists of the Red Air Fleet: approved by the order of the Chairman of the Revolutionary Military Council of the Republic of 24.11.1921 No. 2476. URL: http://www.alppp.ru/law/zakonodatelstvo-ob-oborone/51/prikaz-revvoensoveta-rsfsr-ot-03-11-1921— 2476. html.

7. On the assignment of technical supervision of overhead lines to the General Directorate of the Air Fleet and the organization of the Civil Aviation Council: Resolution of the Labor and Defense Council dated 09/02/1923. URL: https://en.wikipedia.org/wiki/\% D0\% 92\% D0\% BE $\%$ D0 $\%$ B7\% D0 $\%$ B4\% D1\% 83\% D1\% 88\% D0 \% BD $\%$ D1\% 8B $\%$ D0 $\%$ B9 $\%$ D1\% $82 \% \% 81 \%$.

8. History of domestic civil aviation / ed. IA Filatov. Moscow: Air Transport, 1996. 584 p.

9. Civil Code of the Ukrainian SSR 1922. URL: https://yurist online.org/laws/codes/ex/ civilnyi_kodeks_usrr_1922.pdf.10. Air Code of the USSR. 1932 Moscow: RIO Aeroflot, 1932.

11. Air Code of the USSR 1935. Moscow: RIO Aeroflot, 1935.

12. Air Code of the USSR with corrections and additions as of January 1, 1938. Moscow: RIO Aeroflot, 1938.

13. Air Code of the USSR with corrections and additions as of January 1, 1946. Moscow: RIO Aeroflot, 1946.

14. Air Code of the USSR: approved by Decree of the Presidium of the Supreme Soviet of the USSR on December 26, 1961, Wedomosti of the Supreme Soviet of the USSR. 1961. No. 52. Art. 538.

15. Air Code of the USSR: approved by Decree of the Presidium of the Supreme Soviet of the USSR dated 05/11/1983 No. 9275-x. Wedomosti of the Supreme Soviet of the USSR. 1983. No. 20. Art. 303.

16. Air Code of Ukraine dated 04.05.1993 № 3167-XII. Information of the Verkhovna Rada of Ukraine. 25. № 25. Art. 274.

17. About the property: Law of the USSR of February 7, 1991 No. 697-XII. Information of the Supreme Soviet of the USSR. 1991. No. 20. Art. 249. 
18. On Entrepreneurship: Law of the USSR of 7.021991, No. 698-XII. Information of the Supreme Soviet of the USSR. 1991. № 14. Art. 168.

19. Civil Code of Ukraine, dated January 16, 2003, No. 435-IV. Official Bulletin of Ukraine. 2003. № 11. Art. 461.

20. Air Code of Ukraine dated May 19, 2011, No. 3393-VI. Information of the Verkhovna Rada of Ukraine. 2011. № 48-49. Art. 536.

21. On approval of the Aviation Rules of Ukraine «Procedure for granting and cancellation of the rights for operation of overhead lines»: Order of the State Aviation Service of Ukraine dated October 24, 2014 No. 686. Official Bulletin of Ukraine. 2015. № 42. Art. 1345.

22. On the International Treaties of Ukraine: Law of Ukraine of 29.06.2004 No. 1906-IV. Information of the Verkhovna Rada of Ukraine. 2004. № 50. Art. 540.

23. On Private International Law: Law of Ukraine of 23.06.2005 No. 2709-IV. Information of the Verkhovna Rada of Ukraine. 2005. № 32. Art. 422.

24. Convention on the Regulation of Air Navigation (Paris Convention) of 13.10.1919 URL: http://www. spacelaw. olemiss. edu/library/aviation /IntAgr/ multilateral/1919_Paris_conevention. pdf.

25. Ibero-American (Madrid) Convention on Air Navigation. URL: http://www.sct.gob.mx/ fileadmin/_migrated/content_uploads/3_Decreto_por_el_cual_se_promulga_el_Convenio_Iberoa mericano.pdf.

26. Pan-American (Havana) Convention on Civil Aviation, 20.02.1928. URL: https:// www.loc.gov/law/help/us-treaties/bevans/m-ust000002-0698. pdf.

27. Warsaw Convention of 1929 on the Unification of Certain Rules Relating to International Air Transport (Hamburg Rules), Warsaw, 10/12/1929 URL: http://www.afr.kz/index_f/ warsaw-convention_protocol. pdf.

28. Airplane Transit Convention (Buenos Aires Convention), 19.06.1935. URL: http:// www.sct.gob.mx/JURE/doc/160-transito-aviones-1935. pdf.

29. Chicago Convention on International Civil Aviation, 07.12.1944. URL: http://zakon2. rada.gov.ua/laws/show/995_038.

30. Regarding market access to groundhandling services at Community airports: Council Directive № 96/67 / EC of the European Community of 15.10.1996 URL: http://www.amc. gov.ua/amku/doccatalog/ document?id = 132043\&schema $=$ main.

Спасибо В. В. Генезис нормативно-правового регулирования аэропортового обслуживания в Украине.

В статье исследованы генезис норлативно-правового регулирования гражданских правоотношений по аэропортоволу обслуживанию в Украине. Сделан вывод, что деятельность по аэропортоволу обслуживанию регулируется не только норлали Гражданского и Воздушного кодексов и Авиационных правил Украины, но и норлали адлинистративного, хозяйственного, налогового, трудового, экологического, зелельного отечественного законодательства и другили его отрасляли.

Ключевые слова: норлативно-правовое регулирование, гражданско-правовые отношения, гражданское законодательство, аэропортовое обслуживание, Воздушный кодекс Украины, Авиационные правила Украины.

Spasybo $V . V$. Genesis of legal regulation of airport services in Ukraine.

The study of the genesis of legal regulation of relations in the provision of airport services allows us to draw the following conclusions. Airport services and their legislative regulation are directly related to air transportation services. With the expansion of the scope of these services, airport services also developed. These types of services began to take shape in the early XX century and rapidly developed with the creation of a network of airports around the world, including in Ukraine. At the same time, legislative regulation was formed as a set of rules governing transportation, then legislation on the provision of services joined it.

It was established that civil legislation on airport activities historically supplemented the legislation on air transportation, the main purpose of which was to comply with air safety guarantees. A peculiarity of the civil legislation of Ukraine governing the activities of airport 
services is that its basic norms are not contained in the Civil Code of Ukraine, but in the norms of other legislative and by-laws, primarily in the Air Code and the Aviation Rules of Ukraine, as well as in the administrative, economic, tax, labor, environmental, land and other branches of law. However, the core of this set of norms is precisely the rules of civil law, which allows you to regulate these relationships using the principles and methods of civil law and at the same time take into account the links between the various branches of legislation as elements of the system.

It is concluded that the legislation of Ukraine on the provision of airport services should be developed in the process of its unification with EU directives, standards and recommended practices of the International Civil Aviation Organization, due to the global processes of the impact of globalization on these relations and international obligations undertaken by Ukraine.

Key words: legal regulation, civil law relations, civil law, airport service, Air Code of Ukraine, Aviation Rules of Ukraine.
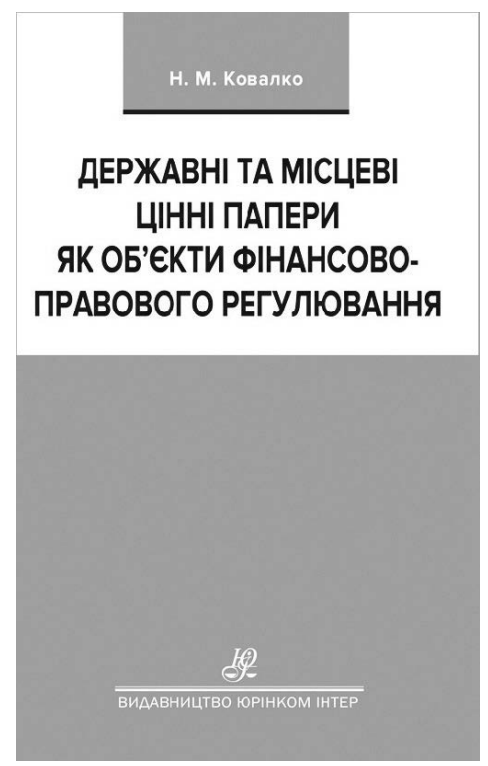

Н. М. Ковалко. Державні та місцеві цінні папери як об’єкти фінансово-правового регулювання: монографія. Київ: Юрінком Інтер, 2019. 328 с.

\section{ISBN 978-966-667-739-9}

У монографії аналізуються нормативно-правові акти, що стосуються відносин у сфері фінансово-правового регулювання обігу державних $\mathrm{i}$ місцевих цінних паперів та пов'язаних із ними відносин. Використано фінансове законодавство деяких зарубіжних країн та висвітлено практику його застосування. Розглянуто становлення та розвиток законодавства України, що регулює відносини у галузі державних і місцевих цінних паперів. Наведено науково обгрунтовані визначення понять «публічний кредит», «публічний борг», «боргові державні та місцеві цінні папери» тощо. Проаналізовано сучасний стан та перспективи державного регулювання й саморегулювання на ринку цінних паперів. Досліджено позиковий капітал і кредитні відносини як публічно-правові явища. Приділяється особлива увага фінансово-правовій природі боргових державних і місцевих цінних паперів. Висвітлюються питання суб'єктів регулювання та контролю у сфері відносин, пов'язаних із державними та місцевими цінними паперами.

На основі аналізу вітчизняного та зарубіжного фінансового законодавства сформульовано низку положень і рекомендацій, що мають важливе теоретичне і практичне значення.

Може бути корисною для викладачів юридичних навчальних закладів і факультетів, аспірантів, студентів, працівників фінансово-кредитних установ, суб’єктів публічної фінансової діяльності. 